\title{
O engajamento das Igrejas na política: o caso dos pentecostais ${ }^{1}$
}

\section{Church engagement in Politics: the case of Pentecostals}

David Mesquiati de Oliveira

\section{Resumo}

Quando o assunto é participação política, os pentecostais estiveram à sombra de outros grupos cristãos por muito tempo. Como grupos minoritários centrados em disputas doutrinárias não tinham pretensões na arena política ou se sentiam já representados. A percepção muda com o aumento do número de adeptos na segunda metade do século XX - lê-se, mais força eleitoral -, com as mudanças na sociedade tradicional e com a abertura política após o enfraquecimento do regime militar em meados da década de 1980, com a Assembleia Constituinte. Principiam uma atuação mais organizada e corporativa, que indicava o surgimento de uma agenda religiosa. O questionamento que orienta o artigo é: Quais as consequências de se transformar a relação entre Igreja e Política em um projeto de poder centrado nos interesses corporativos? Que lugar caberia às Igrejas na participação política nacional? O objetivo é pensar o engajamento das Igrejas na política para além do alinhamento acrítico que se verifica em muitos setores na atualidade. Como percurso metodológico tomará a atuação dos pentecostais, embora as reflexões possam referir-se a outras Igrejas.

Palavras-chave: Igreja. Política. Pentecostais.

\footnotetext{
${ }^{1} \mathrm{O}$ artigo é uma adaptação de uma palestra proferida no Panel Kirche-Macht-Politik por ocasião do evento Deutscher Evangelischer Kirchentag na cidade de Dortmund, Alemanha, entre os dias 19-23 de junho de 2019.
} 


\begin{abstract}
When it comes to political participation, Pentecostals were in the shadow of other Christian groups for a long time. As minority groups centered on doctrinal disputes, they had no pretensions in the political arena or they already felt represented. The perception changed with the increase in the number of supporters in the second half of the 20th century - that is, more electoral strength -, with the changes in the traditional society model and with the political opening after the weakening of the military regime in the mid-1980s, with the Constituent Assembly. They begin a more organized and corporate action, which indicated the emergence of a religious agenda. The question that guides the article is: What are the consequences of turning the relationship between Church and Politics into a power project centered on corporate interests? What place would churches have in national political participation? The objective is to think about the Church's engagement in politics beyond the uncritical alignment that is seen in many sectors today. As a methodological path, it will be based on the work of Pentecostals, although reflections may reach other Churches.
\end{abstract}

Keywords: Church. Politics. Pentecostals.

\title{
Introdução
}

Uma das primeiras questões que precisam ser respondidas quando se pensa na relação entre Igreja e Política é a que se relaciona ao poder. Isto é, devese perguntar sobre a motivação do engajamento das Igrejas. A razão é simples: as Igrejas são instituições sociais que têm relativo impacto na sociedade, e em seus planos de ação institucionais lidam com interesses corporativos e com o bem comum. É esperado um equilíbrio entre esses interesses e até uma atuação mais inclinada ao bem comum, para além dos seus próprios interesses, dado o específico do serviço fornecido por esse agente social. Quais as consequências de se transformar a relação entre Igreja e Política em um projeto de poder centrado nos interesses corporativos? Que lugar caberia às Igrejas na participação política nacional? Essas perguntas nortearão a reflexão que se segue. O objetivo é pensar o engajamento das Igrejas na política para além do alinhamento acrítico que se verifica em muitos setores na atualidade. 
Como percurso metodológico tomará como base a atuação dos pentecostais, embora as reflexões possam incluir outras Igrejas.

As Igrejas pentecostais no Brasil alcançaram maior visibilidade social a partir de meados do século XX. Para os atores da política nacional tratavase de um novo nicho eleitoral que tinha potencial de votos e estaria aberto a alianças. Para as lideranças internas do movimento era uma oportunidade de ter os próprios representantes nas casas de leis e na liderança civil. Nesse amálgama sedutor se forjou uma atuação política de conveniência sem o protagonismo do novo grupo religioso, que se contentava com o status de ser aceito em um novo tempo de participação social. Pode-se dizer que nesse primeiro momento não havia uma agenda clara sobre o que se pretendia, pois, a simples visibilidade e atuação entre os poderosos já era um ganho para aqueles que cresceram sendo relegados. As coisas mudam de figura com o desgaste do regime militar, com a convocação para a Assembleia Constituinte em meados da década de 1980 e com as mudanças no tradicional modelo de sociedade. ${ }^{2}$ É aí que as Igrejas pentecostais se instauram no cenário político formal e rascunham uma agenda, ainda que sem coordenação articulada.

Na primeira seção pretende-se deixar claro que a atuação política das Igrejas em particular e da religião em geral, não é uma novidade do tempo atual e nem deveria ser tratada com espanto. Buscar-se-á defender mais transparência e mecanismos de controle da ação. Na segunda, refletirá sobre o quanto as religiões estão sendo cooptadas pela lógica do mercado e como isso interfere na agenda das Igrejas. Por último, a terceira seção discorrerá sobre a resultante instrumentalização das Igrejas em uma sociedade sob a lógica economicista, que transforma os planos de ação individuais em planos de dominação sobre o outro, relegando à religião um papel paliativo e de sobrevida ao próprio sistema, ao transformá-la em assistencialismo e socorro quando a máquina não funciona para todos - mas funciona eficientemente para alguns grupos e setores.

\section{O lugar do discurso religioso na sociedade}

Se por um lado, o discurso religioso faz parte da sociedade e deve ser assegurada a participação da religião em um Estado democrático de direito, por outro lado, um discurso religioso não pode ver-se como único e impositivo,

${ }^{2}$ PIERUCCI, A. F., Representantes de Deus em Brasília, p. 104-132. 
como se fosse uma verdade inquestionável e válida para todos. Há uma pluralidade de religiões e, do ponto de vista teológico, cada uma conta com estatuto salvífico próprio; e do ponto de vista jurídico, cada uma tem pleno direito de existir nos limites da lei. Como afirmou Faustino Teixeira, "não há como manter uma autêntica sensibilidade dialogal e uma honrada abertura ao outro com perspectivas teológicas acanhadas e inibidoras, que não conseguem visualizar a alteridade senão enquadrando-a em seu horizonte particular". ${ }^{3}$

Em uma democracia todas as vozes devem ser igualmente ouvidas e deve haver uma disposição para a acolhida do outro. Os adeptos de uma determinada religião não podem agir para modelar toda uma nação a partir de suas convicções religiosas próprias, por mais que estejam convencidos de sua fé e do quão boa ela poderia ser para os demais. No dizer de Ariarajah: "Por mais verdadeira que seja nossa experiência, por mais convencidos que estejamos de uma confissão de fé, temos que situá-la como confissão de fé e não como uma verdade em sentido absoluto". ${ }^{4}$ É precisamente aqui que temos uma questão importante e que ajudaria na tratativa do tema: a fé deve ser situada no campo das confissões existenciais e não no campo da imposição ao outro. O exercício livre e democrático da fé é um grande desafio para convicções religiosas estreitas que não comportam outras visões de mundo.

Outro viés interessante é pensar a partir das liberdades em relação ao falar, ouvir e decidir. Cada religioso e seu respectivo grupo tem assegurada a liberdade de fé e de culto, podendo argumentar sobre seu sistema de crenças e professá-lo publicamente. Da mesma forma está assegurada a liberdade para os ouvintes conhecerem sistemas de crenças distintos, reservando-lhes a igual liberdade de acenar positivamente ou não ao recém-escutado. Pensando nessas liberdades há espaço para convivência pacífica entre distintos sistemas de crenças de tal forma que o discurso religioso encontraria seu lugar em diferentes momentos das relações humanas.

Essa percepção poderia dialogar em parte com a posição de Paul Tillich sobre o lugar da religião na sociedade moderna. A partir de uma perspectiva existencialista mais ampla Tillich vai defender que a religião não poderia se acomodar a uma área específica da vida ou da sociedade, porque isso implicaria em um reducionismo da mesma e redundaria em sua irrelevância. A religião desempenharia melhor papel se encontrasse lugar em todas as dimensões

\footnotetext{
${ }^{3}$ TEIXEIRA, F., Indagações em torno da teologia do pluralismo religioso, p. 1.

${ }^{4}$ ARIARAJAH, W., La Bíblia y las gentes de otras religiones, p. 114.
} 
do espírito humano, não como "forma" ou "em dominação", mas sendo a profundidade, ofertando sentido e explicação última. Em suas palavras:

A religião não é mera função especial de nossa vida, mas a dimensão da profundidade presente em todas as funções. [...] Sem lugar próprio, sem ter lugar para habitar, de repente a religião percebe que não precisa de nada disso. Dá-se conta de que já possui seu lugar próprio em todos os lugares, principalmente nas profundezas das funções da vida espiritual humana. [...] Mas que significa a metáfora da profundidade? Quer dizer que o aspecto religioso se volta para os elementos supremos, infinitos e incondicionados da vida espiritual. A religião, no sentido básico e mais abrangente da palavra, é "preocupação suprema" (ultimate concern), manifesta em todas as funções criativas do espírito bem como na esfera moral na qualidade de seriedade incondicional que essa esfera exige. ${ }^{5}$

Nessa perspectiva a religião não demanda um lugar específico, pois atua em uma instância mais ampla conferindo significado último, capacidade de julgamento e coragem criadora ao espírito humano. Mundo secular e religião estariam unidos inseparavelmente, uma vez que a religião aparece dando-lhe substância. Ao mesmo tempo, Tillich faz um alerta:

[A religião] dá-nos a experiência do sagrado, intangível, tremendamente inspirador, significado total e fonte de coragem suprema. Mas, além dessa glória, também aparece sua vergonha, quando ela se transforma em absoluto e despreza o mundo secular; quando faz de seus mitos e doutrinas, de suas leis e ritos, dimensões indiscutíveis e persegue os que não se submetem a isso. ${ }^{6}$

Sua glória e vergonha são separados por uma linha tênue entre o estar a serviço de conferindo sentido (preocupação suprema) ao mundo secular e de submeter todos à sua perspectiva (alienação trágica). Sendo mais específico em relação às Igrejas, Tillich afirmou: “A Igreja, no seu papel profético, é a guardiã que revela as estruturas dinâmicas da sociedade e se opõe a seu poder demoníaco, revelando-o, mesmo quando dentro dela. Ao assim fazer, a Igreja ouve, também, as vozes proféticas fora dela, que julgam a cultura e a ela mesma como sua parte". ${ }^{7}$ Mais adiante ele concluiu:

\footnotetext{
${ }^{5}$ TILLICH, P., Teologia da cultura, p. 42, 44.

${ }^{6}$ TILLICH, P., Teologia da cultura, p. 45.

${ }^{7}$ TILLICH, P., Teologia da cultura, p. 92.
} 
Julgar significa observar os dois lados da realidade. Quando a Igreja julga a cultura, precisa incluir aí as suas próprias formas de vida. Pois suas formas são criadas pela cultura, assim como sua substância religiosa torna possível a cultura. A Igreja está dentro da cultura e vice-versa. E o Reino de Deus as inclui ao mesmo tempo em que as transcende. ${ }^{8}$

Temos assim, o discurso religioso presente na sociedade de forma ampla por meio das imbricações entre cultura, sociedade e religião. Mesmo quando o discurso religioso não está tão evidente, é possível encontrá-lo sedimentado como cultura, seja pelo acatamento da proposta religiosa ou por conta da secularização. Práticas que antes tinham motivação religiosa explícita hoje são alimentadas também por outros sentimentos e motivações, com diferentes nomes, mas que podem estar alinhados com a religião de maneira profunda. Por isso, a pretensa separação entre religião e política nunca sucedeu. Portanto, se há uma relação, direta ou indireta, é melhor reconhecê-la e definir os critérios da sua atuação do que negá-la e, ainda assim, seguir sob sua influência, para bem ou mal.

A religião tem um discurso poderoso, seja o que está explicitado em seus símbolos tradicionais, seja o que subsiste nas expectativas das pessoas e dos demais agentes sociais em relação à sua atuação. A estratégia "purista", que age como se fosse possível apagar as influências religiosas ou como se os diferentes agentes sociais estivessem separados por fronteiras tão demarcadas que não se sente os seus efeitos mútuos é inadequada. Na verdade, os limites nas sociedades contemporâneas são sempre muito frágeis, são mais penumbras do que linhas claras, frutos de tensões e se mostram cada vez mais fluidos. Por isso é importante perguntar pela motivação das ações e ativar um discernimento criterioso para perceber a natureza das ações das Igrejas na política:

A natureza da participação dos diferentes grupos na política é mais importante do que se há ou não participação. A fase inicial de "não-participação" [dos pentecostais] pode ter variadas razões. É possível que os grupos não se envolvessem porque estavam demasiadamente ocupados com questões espiritualizantes e não queriam enfrentar questões sociais e políticas. Ou, esses grupos se sentiam representados pelas posições políticas conservadoras do status quo e não considerassem necessário reforçá-las.

\footnotetext{
${ }^{8}$ TILLICH, P., Teologia da cultura, p. 93.
} 
Ou ainda, como grupos minoritários e segregados, comportavam-se como uma seita do ponto de vista sociológico, sem pretensões de ser igreja e ter mais envolvimento público. Da mesma forma, a mudança de atitude para uma participação mais ativa pode ter ocorrido justamente pelas mudanças sociais e culturais percebidas na sociedade, justificando a disputa pela manutenção dos costumes tradicionais. Essa mudança estaria mais atrelada à ameaça contra a sociedade tradicional e à percepção de que isso deveria ser defendido do que a uma trivial participação como resultante de mero crescimento numérico. ${ }^{9}$

Do que foi exposto até aqui fica claro: 1) o discurso religioso está presente na sociedade, seja de forma direta por meio dos agentes religiosos ou indireta, quando já está sedimentado na cultura; 2) a questão central não é se as religiões devem ou não participar da esfera pública e sim como atuar, com que motivações; 3) a aparente não-participação na agenda política nacional é uma forma de participação, pois indica que os grupos estariam sendo representados de alguma forma pelo status quo; e 4) a participação mais ativa coincide com as mudanças no modelo de sociedade tradicional, mostrando que grupos se organizaram politicamente para defender um modelo específico de sociedade e farão as alianças necessárias para seguir essa agenda.

Sobre a participação específica dos pentecostais é possível afirmar:

A participação política dos pentecostais é muito recente no cenário brasileiro, basicamente a partir de meados de 1980, sendo que os problemas eleitorais envolvendo autoritarismo e políticas ultraconservadoras estiveram presentes desde o início da jovem república, de tal modo que esse grupo não é o foco do problema. Há os que veem a participação organizada dos pentecostais como um risco à democracia e há os que percebem essa atuação como um amadurecimento da participação social. A primeira suposição é muito questionável. A segunda, precisa ser analisada com mais atenção, pois para ser um jogo democrático, os agentes precisam efetivamente respeitar a diversidade e a pluralidade, isto é, reconhecer o lugar do outro e juntos, construírem a nação. Por isso não defendo aqui acriticamente o conteúdo da atuação pentecostal, mas seu lugar como agente social e político. ${ }^{10}$

\footnotetext{
${ }^{9}$ OLIVEIRA, D. M., Pentecostalismo e Política no Brasil, p. 11.

${ }^{10}$ OLIVEIRA, D. M., Igrejas pentecostais e sua atuação política recente no Brasil, p. 21.
} 
As duas posições apresentadas resumem bem a situação envolvendo a recente articulação dos grupos pentecostais na política. Para um grupo de críticos essa articulação lobista seria nociva à sociedade, pois colocaria em risco a democracia. Para o outro, a maior participação indica um natural amadurecimento do movimento em sua fase institucional, em que busca reafirmar suas posições, e como tal, faz parte do jogo democrático. Embora não se possa ignorar que a frágil democracia esteja em risco, é uma posição que padece de exagero um tanto alarmista, seja pelo contingente populacional pentecostal que é pouco mais de $10 \%$ da população brasileira segundo o último censo oficial, seja pelo potencial dos políticos pentecostais, que não têm protagonismo nem força política para empreitada de tal envergadura. Como bem registrou Saulo Baptista:

Os parlamentares pentecostais somente conseguem compor o chamado "baixo clero" do Congresso Nacional, o que já era previsível, porque eles não provêm de famílias "tradicionais", não estão ligados aos grandes grupos que controlam a economia, nem são veteranos nos meandros da política nacional. A condição de "baixo clero" coloca-os mais vulneráveis à cooptação pelas forças da situação, porque estas controlam os recursos e cargos da máquina burocrática do país. ${ }^{11}$

A segunda posição, a que defende a participação de diferentes grupos na arena política, parece ser a mais adequada. A questão de fundo é que essa participação não se dá livremente, uma vez que existem forças poderosas - e interesses - que cooptam diferentes grupos, como se verá na próxima seção.

\section{Religião, cultura e mercado}

A globalização econômica transformou a sociedade contemporânea em uma sociedade de mercados com dimensões planetárias. Algumas religiões mais do que outras instrumentalizaram essa mercadologização do mundo e se universalizaram, exacerbando a concorrência entre religiões como sistemas competitivos, desembocando em um excesso de ofertas de sentido que por sua vez, resulta em um enfraquecimento das religiões. Com esse reposicionamento das religiões como mercado religioso, o próprio mercado surge como lugar de sentido reivindicando sacralidade intrínseca. Assim, vivemos a sacralização do

${ }^{11}$ BAPTISTA, S., Pentecostais e neopentecostais na política brasileira, p. 391. 
mercado como substância da vida. Jung Mo Sung afirmou: "Hoje a 'ilusão do poder' não se dá tanto na esfera política, mas sim na do mercado. A hegemonia neoliberal no mundo consolidou, no final do século XX, o mercado como o fundamento e o centro das nossas sociedades". ${ }^{12}$

O encapsulamento da religião e da cultura pelo mercado gerou um novo tipo de sociedade economicista baseado na utilidade, nos ganhos e no domínio do concorrente. Sendo os desejos mais profundos do ser humano informados pela religião e a função da mercadoria a de satisfazer fantasias, criou-se uma profunda relação entre religião, mercadoria e desejo. ${ }^{13}$ Para encobrir as injustiças resultantes do sistema centralizador de produção, distribuição e consumo o capital privado necessita apelar para a metafísica e acionar a religião. O mercado passa a cumprir a função de um sistema religioso opressor sem regulamentos:

Ídolos são os deuses da opressão. Biblicamente, o conceito de ídolo e idolatria está diretamente vinculado à manipulação de símbolos religiosos para criar sujeições, legitimar opressões e apoiar poderes dominadores na organização do convívio humano. No interior dos processos de intercâmbio valorativo entre os homens, a troca simbólica de objetos e representações de cunho sagrado costuma preservar uma "utilidade", isto é, um aspecto útil ou valor de uso. Fascinados por essa "serventia" dos seus deuses, os seres humanos se entregam prazerosamente a eles. Consumindo-os (já que os mitos são bons para serem comidos), os homens perdem em geral a consciência de que existem deuses devoradores da vida humana. Os ídolos são implacáveis em suas exigências de sacrifícios. ${ }^{14}$

A sacralização do mercado tornou-se mais evidente com o uso indiscriminado de analogias das promessas bíblicas com as promessas da economia de um "novo tempo" em termos messiânicos, bem como o uso inescrupuloso de textos bíblicos em campanhas políticas, além de instrumentalizar a religião como empresa de serviços religiosos:

Quanto maior a liberalização do mercado religioso, esse outro nome sociológico da liberdade religiosa, tanto mais dinamizada fica a concorrência entre as agências de salvação. Isso força as empresas de bens religiosos a

\footnotetext{
${ }^{12}$ SUNG, J., Desejo, mercado e religião, p. 9.

${ }^{13}$ SUNG, J., Desejo, mercado e religião, p. 10.

${ }^{14}$ ASSMANN, H.; HINKELAMMERT, F., A idolatria do mercado, p. 11.
} 
produzirem (depressa) resultados palpáveis, seja para os clientes, seja para si mesmas. Para os clientes, os resultados buscados devem aparecer no mínimo sob a forma de experiências religiosas imediatamente satisfatórias - o êxtase, o transe, o júbilo, o choro, o alívio, enfim, a emoção - ou terapeuticamente eficazes e, no máximo, sob a forma de prosperidade econômica real; para as empresas religiosas (igrejas e cultos), os resultados visados se põem em termos de crescimento e faturamento da organização, expansão da clientela, fixação mercadológica de suas marcas diferenciais e popularidade das lideranças-ícone. ${ }^{15}$

Antonio Flavio Pierucci também observou: "na acirrada disputa por novos seguidores, muitas religiões, em sua atual expressão em nosso país, estão deixando de ser fontes de valores éticos e se transformando em pontos de oferta de serviços de cunho mágico-místico". ${ }^{16}$ E desenvolve sua argumentação:

Se o longo processo histórico de desencantamento do mundo levado a cabo pela religiosidade judaico-cristã da qual nasceu a modernidade ocidental foi, a um só tempo e no mesmo movimento, o processo de se constituírem historicamente como éticas religiosas o judaísmo e o cristianismo e, no seu bojo, o protestantismo, noutras palavras, se o processo de desencantamento do mundo, em seu primeiro momento de longa duração, foi um processo de moralização religiosa, então o atual fenômeno da magificação acelerada das religiosidades na modernidade tardia pode perfeitamente ser considerado um processo de des-moralização religiosa, sendo produzida no mesmo movimento e à mesma velocidade pós-moderna do consumo frívolo de serviços pessoais: para se oferecerem mercadologicamente como soluções mágicas ou experiências místicas, as religiões se mostram cada vez menos ascéticas e moralizantes. ${ }^{17}$

Nesse modelo economicista de sociedade naturaliza-se a concorrência e a nomeação de adversários. O pentecostalismo moderno como grupo mais recente no campo religioso brasileiro, ao afirmar sua identidade nomeou dois grandes inimigos dando coesão ao grupo. De um lado, a religião majoritária no país, o catolicismo, e de outro, uma ideologia que contestava o sistema tradicional de sociedade, o comunismo.

\footnotetext{
${ }^{15}$ PIERUCCI, A. F., Religião.

${ }^{16}$ PIERUCCI, A. F., Religião.

${ }^{17}$ PIERUCCI, A. F., Religião.
} 
As relações entre pentecostalismo e catolicismo no Brasil foram marcadas por enfrentamentos e mútuas agressões. Diferenciar-se do catolicismo era, no início, uma questão de identidade. $\mathrm{O}$ novo grupo enfatizava a vivência da fé em outras categorias que não as católicas. Nesse afã gerou embates e negação do catolicismo como expressão legítima da fé cristã, transformando os católicos em "campo missionário". Do lado católico, o pentecostalismo foi duramente negado. Contudo, no final do século XX, a articulação dos pentecostais na política relativiza essa inimizade quando o tema em tela é a defesa da sociedade tradicional e algumas pautas como "família", "ideologia de gênero", "drogas", etc. Nesses pontos tanto a Frente Parlamentar Evangélica quanto as Frentes católicas se unem invejavelmente, confirmando a máxima: "diante de um inimigo maior, os inimigos menores se unem". Uma vez cessado o interesse na polarização, mormente próximo aos pleitos eleitorais, os grupos são liberados da pauta para voltarem às suas antigas rivalidades, até que se faça uma nova e conveniente chamada, segundo os interesses de plantão.

O segundo inimigo, o comunismo, foi um instrumento importante para controlar as massas. Como bem afirmou François Houtart:

O anticomunismo é uma arma eficaz que proporciona uma consciência. Alguns de seus adeptos sentem-se os cruzados dos tempos modernos, revestidos de uma armadura cintilante que encobre motivos sórdidos. $\mathrm{O}$ anticomunismo é um meio cômodo de abater os inimigos políticos. A recente "revolução" brasileira é um exemplo chocante disso. Frequentemente, as etiquetas democráticas escondem conteúdos reacionários. Não é vinho novo que se coloca em odres usados, mas vinho velho que se põe em odres novos. $^{18}$

Gustavo di Santo analisou o pentecostalismo brasileiro e percebeu, a partir de categorias weberianas, uma afinidade eletiva entre os pentecostalismos e o que ele chamou de "capitalismo democrático", evidenciando uma preferência pela perspectiva liberal. ${ }^{19}$ Esse liberalismo apareceu nos valores relacionados à noção de trabalho, realização pessoal, propriedade privada, privatização etc. que indicam o quanto o movimento esteve propenso às agendas neoliberais. Em âmbito micro, os pentecostais se mostraram comunitários e contribuíram para uma transformação profunda nos indivíduos. Mas em âmbito macro,

\footnotetext{
${ }^{18}$ HOUTART, F. apud BITTENCOURT FILHO, J., Matriz religiosa brasileira, p. 129.

${ }^{19}$ SANTO, G., Valori Religiosi e Sviluppo in Brasile.
} 
não houve uma reflexão mais crítica. Além disso, há o aspecto valorativo em relação à forma como se descreve a esquerda e o comunismo, sempre em tom pejorativo. No dizer de Baptista: “daí a distância que pentecostais e neopentecostais continuam mantendo com relação aos movimentos populares, pois veem resquícios de comunismo nessas formas de organização das lutas sociais". ${ }^{20}$ Comblin já tinha percebido: "os neoconservadores opõem-se vigorosamente ao socialismo, mas não ao liberalismo. Pode ser que, na teoria, ambas as ideologias sejam condenadas. Porém, na prática somente se aceita a ideologia neoliberal [...] à qual oferece cobertura e legitimação". ${ }^{21}$ Apesar de dirigida ao catolicismo de sua época, a crítica vale para os demais grupos.

A religião toca o mais profundo do espírito humano, mas a religião foi cooptada pelo mercado que instrumentalizou essa força para interesses privados. Mesmo sem se dar conta, as religiões podem estar se prestando a esse papel. Há uma demanda urgente por profetismo no estilo bíblico que desperte as Igrejas para a defesa da justiça e para a busca do bem comum.

\section{Resistir à instrumentalização da religião}

Coube à religião um papel diminuto nas sociedades contemporâneas apesar de ampla capilaridade. Restaram duas opções: ou a religião virava uma simples mercadoria para satisfazer as demandas hedonistas da sociedade ou se reduziria à condição de mera funcionalidade, onde será convocada para dar mais fôlego ao sistema, aliviando as mazelas produzidas pela mentalidade predatória e consumista do mundo atual. Para fugir desse falso dilema a religião precisa de autocrítica e retomar sua função como voz da consciência para os demais agentes sociais, recuperando sua capacidade de influir para a ação dando um sentido mais elevado, lembrando das coisas últimas e não das meramente utilitárias. Esse tipo de religião será visto pelo sistema vigente como um tipo de entrave, algo que impede o desenvolvimento e que limita o capital. Tal como nos tempos do Novo Testamento, os convites dos grandes e poderosos continuam assediando as lideranças proféticas para que se alinhem e se tornem dependentes das benesses do sistema.

Jesus exerceu o profetismo na esteira dos profetas reformadores sociais de forma poderosa e:

\footnotetext{
${ }^{20}$ BAPTISTA, S., Pentecostais e neopentecostais na política brasileira, p. 387.

${ }^{21}$ COMBLIN, J., O neoliberalismo, p. 84.
} 
Não somente era um profeta semelhante a eles, mas realizou o modelo - o exemplo perfeito de profeta. Desse modo, os profetas da antiga Lei foram vistos como precursores, como preparação do papel profético de Jesus. Nessa condição, Jesus inaugurou um novo jeito de ser profeta - que passa a ser modelo desde então e que perdura até hoje. ${ }^{22}$

Comblin auxilia na reflexão para resgatar essa percepção profética das Igrejas e deixa claro que "uma palavra dependente nunca será uma palavra profética", uma vez que se coloca em submissão à ordem estabelecida. E continua: "o profeta é a pessoa que se faz a voz dos que não têm voz, e somente pode receber inspiração no mundo dos pobres". Mais adiante se pergunta sobre negociações e concessões diante do mundo: "nesse caso, quem é que se converte? Será a elite ou será o setor da Igreja que a acolhe sem perceber que está sendo manipulado?". ${ }^{23}$ Uma vez mais, essas palavras foram críticas ao catolicismo, mas se aplicam profeticamente ao pentecostalismo atual.

O profeta João Batista não aliviou a crítica a Herodes e por conta disso foi preso e morto. Nos evangelhos é narrada sua morte:

Com efeito, Herodes havia mandado prender e acorrentar João, e o tinha mandado meter na prisão por causa de Herodíades, esposa de seu irmão Filipe. João lhe tinha dito: Não te é permitido tomá-la por mulher! De boa mente o mandaria matar; temia, porém, o povo que considerava João um profeta (Mt 14,3-5).

Seguramente João não se confraternizava com os que oprimiam o povo. ${ }^{24}$ Aliás, só esteve presente no palácio depois que foi decapitado e jazia com o corpo inerte: "e mandou [o rei Herodes] decapitar João na sua prisão. A cabeça foi trazida num prato e dada à moça, que a entregou à sua mãe [no palácio]"

${ }^{22}$ COMBLIN, J., A profecia na igreja, p. 52.

${ }^{23}$ COMBLIN, J., A profecia na igreja, p. 264.

${ }^{24}$ No evangelho de São Mateus narra-se o infanticídio levado a cabo quando o rei soube de uma profecia que falava sobre o nascimento de um libertador para os judeus: "E, tendo nascido Jesus em Belém de Judéia, no tempo do rei Herodes, eis que uns magos vieram do oriente a Jerusalém, dizendo: Onde está aquele que é nascido rei dos judeus? porque vimos a sua estrela no oriente, e viemos a adorá-lo. E o rei Herodes, ouvindo isto, perturbou-se, e toda Jerusalém com ele. [...]. Então Herodes, vendo que tinha sido iludido pelos magos, irritou-se muito, e mandou matar todos os meninos que havia em Belém, e em todos os seus contornos, de dois anos para baixo, segundo o tempo que diligentemente inquirira dos magos" (Mt 2,1-3.16). 
(Mt 14,10-11). Enquanto viveu exerceu a consciência crítica e a denúncia. Jamais deixou de interpelar e apontar as injustiças. A dimensão profética da Igreja é a denúncia da ordem estabelecida que todos querem esconder. ${ }^{25}$

Assim, a questão de fundo sobre o porquê as forças que representam os interesses privados buscam desqualificar a religião na esfera pública e impedir seu acesso nas discussões dos grandes temas atuais fica parcialmente respondida. Ao mesmo tempo, intentam deslocá-la para o campo da assistência social quando as coisas não saem como deveriam, apelando à pastoral cristã e seu serviço diaconal, que sim são fundamentais, mas que não substituem as políticas públicas nem os deveres morais e sociais relativos à justa distribuição de renda. ${ }^{26}$

Bruna Dantas analisou as principais motivações da atuação pentecostal na política nacional e concluiu que se resumem à defesa de pautas conservadoras relativas à sexualidade e ao corpo, unindo-se a outros grupos de interesses, e do ponto de vista institucional, fortalecimento para enfrentar os "concorrentes" religiosos, especialmente o catolicismo, captação de verbas públicas, concessão de rádio e $\mathrm{TV}$, doação de terreno, entre outros. ${ }^{27} \mathrm{Com}$ essas pautas prevalece não o interesse comum, senão a modelação do mundo à concepção própria de mundo que um determinado agente sustenta. Esse tipo de ação política precisa ser discutido de forma aberta e transparente. As casas de leis são espaços participativos para se criar leis para todos e não para impor

${ }^{25}$ COMBLIN, J., A profecia na igreja, p. 35.

${ }^{26}$ Alguns analistas mais críticos do movimento pentecostal duvidam que a participação política dos mesmos poderia representar algum tipo de benefício para o todo, uma vez que padecem de muitas limitações. Christian Lalive D’Epinay acreditava que os pentecostais estavam organizados em estruturas autoritárias e paternalistas e pouco poderiam oferecer (D'EPINAY, C. L., O refúgio das massas); Jean Pierre Bastian via-os como instrumentos de dominação das massas e a participação política meramente como resultado do crescimento numérico (BASTIAN, J-P., Protestantismos y modernidad Latinoamericana); Andrew Chesnut acusava-os de clientelismo e "voto de cabresto" (CHESNUT, R. A., Born Again in Brazil); Newton Gaskill via-os como ameaça à democracia (GASKILL, N., Rethinking Protestantism and democratic consolidation in Latin America). Contudo, é importante recuperar a fala de Saulo Baptista: "os políticos pentecostais não são melhores nem piores do que seus pares" (BAPTISTA, S., Pentecostais e neopentecostais na política brasileira, p. 393). Tantos outros analistas destacaram os pontos positivos dessa participação, como: DODSON, M., Pentecostals, Politics, and Public Spacer in Latin America; STOLL, D., Is Latin America turning protestant?; MARIZ, C. L., Religion and poverty in Brazil; MARIZ, C. L., Coping with Poverty; LACERDA, F., Pentecostais, clientelismo e política; MACHADO, M. D. C.; BURITY, J., A ascensão política dos pentecostais no Brasil na avaliação de líderes religiosos; entre outros.

${ }^{27}$ DANTAS, B. S. A., Religião e política, p. 24. 
uma visão de mundo particular para terceiros, nem o Estado laico uma fonte a financiar religiões específicas. ${ }^{28}$

\section{Conclusão}

Pode-se afirmar que às religiões deve ser assegurada plena participação na arena política, seja como indivíduo religioso ou como instituição organizada. $\mathrm{O}$ que precisa ser frisado é o ambiente dialogal e propositivo dessa participação, nunca como "mão única". É legítimo buscar os interesses institucionais e melhores condições de subsistência, mas isso não poderia se transformar na missão ou na meta da participação política.

É possível constatar que a religião atua na sociedade através de estruturas formais e da cultura de tal forma que não se trata de questionar se as religiões poderiam atuar ou não na esfera pública e sim perguntar pela natureza dessa participação. Os momentos em que diferentes grupos não se posicionam sobre a agenda política pode ser interpretado como uma forma de participação, pois indica que os grupos estariam sendo representados de alguma forma pelo status quo ou seriam minorias sem efeito sobre o todo. No caso dos pentecostais uma participação mais ativa coincidiu com as mudanças no modelo de sociedade tradicional, em que diferentes grupos se organizaram para defender um modelo específico de sociedade e encontraram nas propostas ultraconservadoras de candidatos populistas e messiânicos um espelho dessa agenda.

Sobre as consequências de se transformar a relação entre Igreja e Política em um projeto de poder centrado nos interesses corporativos fica evidente que traz um enorme prejuízo tanto às religiões por seu descrédito, mas também aos cidadãos que não partilham daquela religião em particular. Nos planos de ação das diferentes Igrejas deve entrar o cuidado com os demais e a busca pelo bem comum.

A perspectiva religiosa como algo profundo, que desperta para as questões últimas, teria mais para contribuir com a sociedade do que somente por meio de ações diaconais de cuidados paliativos. A pastoral é profundamente transformadora, sem embargo, deve ser crítica o suficiente para não ser instrumentalizada pelo mercado.

\footnotetext{
${ }^{28}$ Uma visão crítica da participação política dos pentecostais na política a partir da teologia pentecostal pode ser vista em: OLIVEIRA, D. M., Profetismo bíblico e profetismo pentecostal; OLIVEIRA, D. M., Pentecostalismo e Política no Brasil; OLIVEIRA, D. M., Igrejas pentecostais e sua atuação política recente no Brasil.
} 
A participação das Igrejas pentecostais na política é muito recente, com cerca de quarenta anos, e durante as últimas décadas tem passado por muitas mudanças. É importante que haja diálogo e reflexão teológica imbuída de espírito público e pensando a participação como ministério, como serviço às pessoas e ao mundo. É possível construir uma agenda mais ampla e participativa. É possível ouvir diferentes vozes e construir arranjos para todos além de redescobrir a perspectiva profética que ajudará a não se alinhar com programas e projetos que possam oprimir o povo.

\section{Referências bibliográficas}

ARIARAJAH, W. La Bíblia y las gentes de otras religiones. Santander: Sal Terrae, 1998.

ASSMANN, H.; HINKELAMMERT, F. A idolatria do mercado. Ensaio sobre economia e teologia. São Paulo: Vozes, 1989.

BAPTISTA, S. Pentecostais e neopentecostais na política brasileira. São Paulo: Annablume; São Bernardo do Campo: IMIH, 2009.

BASTIAN, J-P. Protestantismos y modernidad Latinoamericana: historia de unas minorías religiosas activas en América Latina. Mexico: FCE, 1994.

BÍBLIA Sagrada. Trad. João Ferreira de Almeida. Almeida Revista e Atualizada (ARA). São Paulo: SBB, 1993.

BITTENCOURT FILHO, J. Matriz religiosa brasileira. Religiosidade e mudança social. Petrópolis: Vozes, 2003.

CHESNUT, R. A. Born Again in Brazil: The Pentecostal Boom and Pathogens of Poverty. New Brunswick: Rutgers University Press, 1997.

COMBLIN, J. O neoliberalismo. Ideologia dominante na virada do século. Petrópolis: Vozes, 2000.

COMBLIN, J. A profecia na igreja. São Paulo: Paulus, 2008.

D’EPINAY, C. L. O refúgio das massas: estudo sociológico do protestantismo chileno. Rio de Janeiro: Paz e Terra, 1970.

DANTAS, B. S. A. Religião e política: ideologia e ação da "Bancada "Evangélica" na câmara federal. São Paulo, 2011. 350p. Tese. Faculdade de Psicologia, Pontifícia Universidade Católica de São Paulo. 
DODSON, M. Pentecostals, Politics, and Public Spacer in Latin America. In: CleAry, E. L.; STEWART-GAMBINO, H. W. (Eds.). Power, Politics and Pentecostals in Latin America. Boulder: Westview Press, 1997. p. 25-40.

GASKILL, N. Rethinking Protestantism and democratic consolidation in Latin America. Sociology of Religion, v. 58, n. 1, p. 69-91, 1997.

LACERDA, F. Pentecostais, clientelismo e política: uma avaliação da literatura sobre América Latina e Brasil. Cadernos de Pesquisa Política, n. 12, p. 1-44, 2016.

MACHADO, M. D. C.; BURITY, J. A ascensão política dos pentecostais no Brasil na avaliação de líderes religiosos. Dados, v. 57, n. 3, p. 601-629, 2014.

MARIZ, C. L. Religion and poverty in Brazil: a comparison of Catholic and Pentecostal communities. Sociology of Religion, v. 53, p. 63-70, 1992.

MARIZ, C. L. Coping with Poverty: Pentecostals and Christian Base Communities in Brazil. Philadephia: Temple University Press, 1994.

OLIVEIRA, D. M. Profetismo bíblico e profetismo pentecostal: um chamado à transformação social. In: OLIVEIRA, D. M. (Org.). Pentecostalismos e Transformação Social. São Paulo: Fonte Editorial, 2013. p. 39-63.

OLIVEIRA, D. M. Pentecostalismo e Política no Brasil. Interações, v. 14, n. 25, p. 08-12, jun. 2019.

OLIVEIRA, D. M. Igrejas pentecostais e sua atuação política recente no Brasil. Revista Brasileira de História das Religiões, v. 13, n, 37, p. 09-23, 2020.

PIERUCCI, A. F. Representantes de Deus em Brasília: A Bancada Evangélica na Constituinte. Ciências Sociais Hoje, v. 11, p. 104-132, 1989.

PIERUCCI, A. F. Religião. Folha de S. Paulo, São Paulo, 31 dez. 2000. Disponível em: <https://www1.folha.uol.com.br/fsp/mais/fs3112200019. htm>. Acesso em: Acesso em: 22 jul. 2020.

SANTO, G. Valori Religiosi e Sviluppo in Brasile: Cattolicesimo e (Neo)Pentecostalismo verso la convergenza? Cosenza, 2018. 260p. Tesi. Dipartimento di Scienze Politiche e Sociali, Universitá della Calabria.

STOLL, D. Is Latin America turning protestant? Los Angeles: University of California Press, 1990.

SUNG, J. M. Desejo, mercado e religião. São Paulo: Fonte, 2010. 
TEIXEIRA, F. Indagações em torno da teologia do pluralismo religioso. Post scriptum (reflexões de 2005), 2012, p. 1-4. Disponível em: <http:// servicioskoinonia.org/relat/357.htm>. Acesso em: 22 jul. 2020.

TILLICH, P. Teologia da cultura. São Paulo: Fonte Editorial, 2009.

\section{David Mesquiati de Oliveira}

Doutor em Teologia pela Pontifícia Universidade Católica do Rio de Janeiro Docente no Programa de Pós-Graduação em Ciências das Religiões da

Faculdade Unida Vitória / ES - Brasil

E-mail: david@fuv.edu.br

Recebido em: 02/08/2020

Aprovado em: 23/10/2020 